\title{
Evaluation of Readiness for the Professional Development of Medical Practitioners in Terms of Distance Learning
}

\author{
Baiba Avota Mg. sc. sal. \\ Latvia University of Life Sciences and Technologies \\ Riga Medical College of the University of Latvia, Latvia \\ baiba.avota@rmkoledza.lv
}

\begin{abstract}
Nowadays, distance learning provides various benefits like convenience, flexibility, ability to work together and communicate. In Latvia, the professional development of medical practitioners in terms of distance learning is an underdeveloped area, which would require more attention and fulfil one of the strategic objectives of education - promoting lifelong learning. In Latvia, professional development for medical practitioners is still based on traditional educational programme models, this trend is also observed in higher education medical studies. In order to develop the opportunities for medical practitioners to acquire professional development in terms of distance learning, it is essential to understand the readiness of individuals for such a form of study. Readiness in scientific literature is extensively studied in search of the best tool for its evaluation. To acquire knowledge, skills and competences in distance learning studies, participants of the courses need self-motivation, commitment, information, and communication skills. All of these characteristics and skills can affect the effective acquisition of the course. Assessment of distance learning readiness can help distance learning course developers provide the best experience for course participants, anticipate problems and ensure continuity in learning. Taking into account that the author is currently working on developing and implementing distance learning courses for medical practitioners in professional development, assessment of the readiness will help to identify problems for the successful development and implementation of the course. The aim of the study was to assess the readiness of medical practitioners for professional development in terms of distance learning, identifying the factors influencing distance learning. The selected research method is quantitative - a survey. The questionnaire was taken by 247 medical practitioners. The questionnaire included several issues for assessing readiness: motivation, time planning, readiness to use technologies, as well as respondents' experience and attitude to distance learning. The study revealed that distance learning is important and necessary for the professional development of medical practitioners, which is associated with economic benefits. The readiness of medical practitioners is high, $81 \%$ of the respondents have good technological skills and $84 \%$ of the respondents have a high level of motivation to learn. The influential factors the respondents mention in terms of mastering distance learning are as follows: $18 \%$ of time planning problems and $75 \%$ of English language skills. Interactivity, which includes video, audio, self-testing tasks and clinical simulations, is important when developing distance learning courses. Lack of time and time planning are one of the factors influencing distance learning, therefore, student support and advice is an important condition for the realization of any distance learning course.
\end{abstract}

Keywords: adult education, distance learning, e-studies, lifelong learning, readiness, digital tools.

\section{Introduction}

In many countries of the world, distance learning has established itself in the educational system, including the medical field. Medicine is the field in which, in addition to theoretical knowledge, critical thinking and experience is essential, it is therefore necessary to prepare teaching materials in such a way that these competences and knowledge are also acquired in the form of distance learning. Therefore, often in the study process, distance learning studies are combined with intramural studies (Smith, Passmore, Faught, 2009; Bullock et al., 2013; Clark, Frith, 2013).

The concept of distance learning is used in many ways - open studies, e-studies, online learning, and virtual studies; more often it refers to a method that supplies educational information through the Internet. This kind of learning provides different but, at the same time, a better learning experience (Bates, 2016). At present, Massive, Open, Online Courses - MOOC, which was first used in 2008, has gained enormous popularity. The University of Manitoba in Canada offers such a course, which is open and accessible to everyone. The largest number of participants registered for this course was 250,000. In Europe, around 1,000 MOOC courses were available in 2015 (Bates, 2016). In literature, distance 
learning involves a variety of strategic learning and technology (Mercado, 2008), which plays an important role in education.

Timeliness of the topic is due to the fact that education in the $21^{\text {st }}$ century is marked by issues such as globalization, human migration, information transformation in society, increased competition in the economy, the impact of information and communication technologies affecting all aspects of life, including education (Ozgur, Kocak, 2016). Education has played a major role in recent years not only in improving the productivity of the national labour market, but also in helping individuals improve their employability in rapidly changing socio-economic conditions, and thus the role of distance learning in vocational education is very topical and necessary (Open and Distance..., 2002). Today, attention is focused on a flexible learning environment, professional development programmes and interpersonal training in order to ensure that the healthcare workforce is properly trained to practice in the field of healthcare (Continuing Education..., 2011).

It is important to emphasize that the adult student community is rather heterogeneous. In general, they differ in the following characteristics from the traditional student community (Merriam, Cafarella, Baumgartner, 2007; Knowles, Holton, Swanson, 2015): a high level of motivation, characterized by the fact that he or she decides to continue his or her education consciously and is very motivated to achieve results; the focus on learning, characterized by the desire to acquire knowledge and skills that can then be used directly and indirectly in their profession; life and professional experience, which tend to be actively involved in the learning process; willingness and readiness to think independently and critically, thereby favouring independent learning activities; a wide range of responsibilities and a lack of time that can affect the learning process. These qualities are a positive aspect for an adult being able to study in terms of distance learning (Pozdnyakova, Pozdnyakov, 2017). Knowledge in distance learning includes two very closely related, but different parts (Bates, 2016): content that includes facts, ideas, principles, procedures; skills required to gain knowledge - communication skills, ability to study independently, ethics and responsibility, teamwork and flexibility, thinking skills, both critical and problem-oriented thinking, digital skills, knowledge management.

Several factors, such as self-motivation, cooperation with the teaching staff, colleagues, technical skills, learning style, time planning skills and access to technologies can affect the readiness of medical practitioners for distance learning (Hart, 2012; Vasilevska, Rivza, Bogdan, 2017). Authors such as D. Warner, G. Christie, and S. Choy (1998) discuss three aspects of readiness for distance learning: (1) the benefits of distance learning as opposed to an intramural form of study; (2) students' confidence in electronic communication and competence in the use of computers and the Internet; (3) the ability to engage in independent learning (Hung et al. 2010). The author M. McVay (2001) developed a broad tool for assessing readiness that focused on student behaviour and attitude in order to clarify the concept of readiness. This tool was used in the study by author P.J. Smith (Smith et al., 2003), which confirmed two important parts for readiness - "e-learning comfort" and "self-governance". In his publication, the author C.A. Mercado (2008) provides a scale for distance learning assessment readiness, which includes several parts: technology provision, student and teaching staff technology literacy, the attitudes of the student and teaching staff towards studies and organizational readiness. The scales for distance learning assessment readiness are closely related to distance learning quality criteria and qualitative study course process (Pawlowski, 2007; E-learning Quality..., 2008; Poljanowicz et al., 2014).

Distance learning is a proven and necessary teaching and learning method that requires interdisciplinary cooperation between teaching staff and IT teams. A well-designed and implemented online course may remain useful for many years, but it needs to be improved, adapted and updated, and any such improvements and updates should be included in the academic hours of the teaching staff (Poljanowicz et al., 2014). Distance learning allows students to adapt to different learning activities, the need to make decisions independently, control their learning activities, choose the appropriate learning pace; therefore, students' readiness to learn distance learning becomes an important part of the assessment for both distance learning participants and developers of distance learning courses (Hung et al., 2010).

The aim of the research is to assess the readiness of medical practitioners to acquire professional development courses in terms of distance learning, identifying the factors influencing distance learning. 


\section{Methodology}

To assess the readiness of medical practitioners, a quantitative research method has been selected. Any medical practitioner who has a medical education could take part in the questionnaire. In order to achieve the aim of the study, the readiness of medical practitioners was assessed from several aspects: (1) technology skills and provision, (2) motivation to learn, (3) digital teaching tools for distance learning and previous experience. The questionnaire was prepared electronically and sent to the personal emails of medical practitioners available on the website of the Ministry of Health of the Republic of Latvia; emails were also sent to health institutions. In total, about 1200 emails were sent with an invitation to participate in the questionnaire. The study was attended by 247 medical practitioners aged 21-74. The research data were obtained in the period October $30^{\text {th }}$ through to November $10^{\text {th }}, 2017$. The results obtained are summarized using the Statistical Package for the Social Sciences - SPSS version 20.0. The results are summarized in tables.

\section{Results and Discussion}

The study was attended by 247 medical practitioners aged 21-74. A large number of medical practitioners were aged 41-55 (49\%), while $15 \%$ of respondents were between the ages of 56 and 74, especially in the group of doctors, $20 \%$. This tendency reflects the problem characterized for Latvia a large number of healthcare sector workers are at pre-retirement age, and there is a lack of young healthcare sector workers, which in turn can affect healthcare as a whole, as well as readiness for the use of new technologies (Par pamatnostadnem..., 2005).

Of the respondents who participated in the study, $52 \%$ were nurses, $23 \%$ physician assistants, $22 \%$ doctors and $3 \%$ other medical practitioners. Summarizing the results of the need for distance learning, $95 \%$ of respondents believe that distance learning is important and necessary for professional development. Respondents associate this with an economic benefit, which in turn accounts for $40 \%$ of time saving and $19 \%$ of financial saving. The result can be explained by the workload, responsibility for continuity of care and other personal factors of medical practitioners.

The study included medical practitioners from different areas of practice in the regions of Latvia (Table1). The main criterion was the distance from the capital, which is mentioned as one of the factors contributing to distance learning in the literature, saving time and reducing the cost of learning. Such a criterion is important in this study, as most of the professional development training courses take place in Riga, which makes it difficult to attend courses and increases the cost of the course.

Table 1

Motivation for Studying by Distance Learning in Relation to the Distance from the Capital to the Place of Practice $(\%)(n=247)$

\begin{tabular}{|c|c|c|c|c|c|}
\hline \multirow{2}{*}{$\begin{array}{l}\text { Characterization of the practice place } \\
\text { distance }\end{array}$} & \multicolumn{4}{|c|}{ I am motivated for distance learning } & \multirow{2}{*}{$\begin{array}{c}\text { Total } \\
\text { Distributi } \\
\text { on }\end{array}$} \\
\hline & $\begin{array}{l}\text { Fully } \\
\text { agree }\end{array}$ & $\begin{array}{c}\text { Agre } \\
\text { e }\end{array}$ & $\begin{array}{c}\text { Partly } \\
\text { agree }\end{array}$ & $\begin{array}{l}\text { Disagr } \\
\text { ee }\end{array}$ & \\
\hline Riga Region & 20 & 15 & 7 & 4 & 47 \\
\hline Regions outside Riga $(<50 \mathrm{~km})$ & 7 & 4 & 2 & 0 & 13 \\
\hline Remote rural and city region (> $50 \mathrm{~km})$ & 20 & 16 & 4 & 1 & 40 \\
\hline Total distribution among assessments & 48 & 36 & 12 & 4 & 100 \\
\hline
\end{tabular}

When analysing the data, there are no significant differences between distance and motivation to study (Table 1), since summarizing "Fully agree" and "Agree" within the Riga Region, $35 \%$ of respondents are motivated to study in terms of distance learning, while $36 \%$ of respondents in remote rural and urban areas $(>50 \mathrm{~km})$ are motivated to study in terms of distance learning.

Overall, the result shows that $84 \%$ of respondents are motivated to study in terms of distance learning, regardless of the region in which they live and practice. Also, the result may be related to the fact that in the outermost regions of the rural and urban areas, professional development training courses for medical practitioners are provided. In contrast, analysing open question entries shows the importance of distance in professional development. Quotes from the respondents' entries: 
Respondent 1: "Distance learning must be developed. It would be especially useful if the 2-hour association meetings would be recorded and made available online at least for a price, because going to such a session, which takes place in Riga, the whole day is spent, but the benefit is 2 further education points".

Respondent 2: "Taking into account that medical practitioners are busy working at multiple workplaces, distance learning would be a great opportunity to study for those medical practitioners who cannot attend an intramural form of study (due to different everyday conditions: multiple jobs, children and lack of time)".

Summarizing all the criteria above for the technology skills of medical practitioners for distance learning (during the analysis, the assessments "Fully agree" and "Agree" and the opposite, "Partly agree" and "Disagree" were summarized), the study shows that a total of $81 \%$ of respondents are ready to use technology for distance learning and the use of technology does not cause problems (Table 2). In order to successfully use the distance learning course and complete the tasks, a computer is required and the computer literacy, $90 \%$ of respondents note that they are able to work with a computer, manage and attach files (criterion 1), which is one of the distance learning tasks for successful completion of the course. Despite the technical skills and readiness, the pedagogically useful features of a virtual environment include easy and structured ways of finding information and ways to communicate with colleagues and teaching staff, so the technical infrastructure needs to be strong and convenient to use (E-learning Quality..., 2008).

Assessment of Technical Skills of Medical Practitioners

for Distance Learning $(\%)(n=247)$

\begin{tabular}{|l|c|c|c|c|}
\hline \multicolumn{1}{|c|}{ Technology readiness criteria } & $\begin{array}{c}\text { Fully } \\
\text { agree }\end{array}$ & Agree & $\begin{array}{c}\text { Partly } \\
\text { agree }\end{array}$ & $\begin{array}{c}\text { Dis- } \\
\text { agree }\end{array}$ \\
\hline $\begin{array}{l}\text { 1. I am able to work with a computer, manage and attach } \\
\text { files }\end{array}$ & 62 & 28 & 10 & 0 \\
\hline $\begin{array}{l}\text { 2. I can log in to the course management system and join } \\
\text { the course }\end{array}$ & 42 & 25 & 23 & 10 \\
\hline $\begin{array}{l}\text { 3. I can make payments for the course through the online } \\
\text { bank }\end{array}$ & 83 & 13 & 3 & 1 \\
\hline $\begin{array}{l}\text { 4. I have the technical equipment for distance learning - } \\
\text { computer, headphones, speakerphone, multimedia } \\
\text { software }\end{array}$ & 68 & 17 & 12 & 3 \\
\hline $\begin{array}{l}\text { 5. I have no problems installing the software and } \\
\text { changing settings }\end{array}$ & 38 & 25 & 28 & 9 \\
\hline $\begin{array}{l}\text { 6. I learn new information technology resources very } \\
\text { quickly }\end{array}$ & 39 & 32 & 26 & 3 \\
\hline \multicolumn{1}{|c|}{ Total percentage distribution among assessments } & 56 & 25 & 17 & 2 \\
\hline
\end{tabular}

Often, distance learning materials contain various audio or video files requiring a computer, a speakerphone, multimedia software, and other devices. A majority of respondents (85 \%) (Table 2 , criterion 4) fully agrees and confirms that they have all of these devices to acquire distance learning courses. Nowadays, not only computers, but also mobile devices are used for distance learning, this kind of teaching method is called m-studies, which is outside the scope of this research, although nowadays more and more researches on the integration of $m$-studies in the educational process are found (Baran, 2014). The author focused the research on personal goals by developing a distance learning course for medical practitioners for professional development, and in this course mobile devices can only be an aid for insight into the course, but not for the full acquisition of it.

Assessing the technical skills of the respondents, for $37 \%$ of the respondents more complex technical activities would be difficult, such as software installing and changing settings (Table 2, criterion 5), which means that access to the distance learning course should be simple, without having to install software and making any significant changes to the settings. Also, support and advice are important throughout the distance learning course. 
Nowadays, the majority of on-the-job professional development courses for medical practitioners are for a certain fee, which means that distance learning is only available when the respondent is able to make an automated payment through an online bank. The result of the study shows that $96 \%$ of respondents either fully agree or partly agree with the assertion that they are able to make standard payments via online bank (Table 2, criterion 3), which today is an integral part of the era of technology. Despite the fact that the readiness of technology is owned by $81 \%$ of respondents (fully agree), $19 \%$ of respondents find that technologies can make it difficult to fully participate in distance learning. Also, this result shows that distance learning will not always be an effective form of learning for everyone (Table 2).

Assessing and analysing learning readiness in distance learning Table 3 reflects a positive indicator, as $70 \%$ of respondents are ready to learn, which includes communication and the use of various digital resources, but $30 \%$ of respondents may, however, pose problems in distance learning courses, which, in turn, can affect the continuity of the course.

Table 3

Readiness to Use Distance Learning (\%) $(\mathrm{n}=247)$

\begin{tabular}{|l|c|c|c|c|}
\hline \multicolumn{1}{|c|}{ Readiness criteria for distance learning } & $\begin{array}{c}\text { Fully } \\
\text { agree }\end{array}$ & Agree & $\begin{array}{c}\text { Partly } \\
\text { agree }\end{array}$ & Disagree, \\
\hline 1. I am motivated to use distance learning. & 48 & 36 & 12 & 4 \\
\hline $\begin{array}{l}\text { 2. I plan my work ahead to be able to fulfil the tasks } \\
\text { assigned. }\end{array}$ & 36 & 46 & 14 & 4 \\
\hline $\begin{array}{l}\text { 3. I am ready to spend at least 5 hours each week to } \\
\text { take a distance learning course. }\end{array}$ & 22 & 28 & 34 & 16 \\
\hline $\begin{array}{l}\text { 4. I am ready to send an email or to take part in } \\
\text { conversations with people whom I have never met. }\end{array}$ & 20 & 33 & 32 & 15 \\
\hline $\begin{array}{l}\text { 5. The presence of Readable materials is important } \\
\text { for me. }\end{array}$ & 51 & 38 & 10 & 1 \\
\hline 6. I can learn from things that I see and hear. & 43 & 49 & 7 & 1 \\
\hline 7. I can study the distance learning course in English. & 9 & 16 & 30 & 45 \\
\hline 8. Quick feedback is important for me. & 29 & 49 & 19 & 3 \\
\hline $\begin{array}{l}\text { 9. It is important to me that I am completely } \\
\text { independent in the distance learning course. }\end{array}$ & 41 & 42 & 15 & 2 \\
\hline Total percentage distribution among assessments & 34 & 37 & 19 & 10 \\
\hline
\end{tabular}

This inefficiency can be improved if the course developer uses widely available online study materials and they are in English, as $75 \%$ of respondents note that they are partially or totally unable to acquire a distance learning course that includes English materials (Table 3, criterion 7), although the motivation to use distance learning (criterion 1) is high (84\%).

An interesting indicator is that $83 \%$ of respondents want to be independent in the distance learning course (Table 3, criterion 9), which shows the trend if the distance learning course is done online, such as webinars, when the course participant has to be present at a set time in a certain place at a computer having an Internet connection, then such a distance learning course may not be used. The result is due to the aforementioned lack of time. Independent distance learning courses could be more effective in terms of how the course participant independently performs certain tasks step-by-step, reads, listens to audio and video lectures. This factor allows the course participant to take a distance learning course, regardless of time and place.

One of the readiness indicators is self-motivation, which includes the desire to learn and plan time for learning. A positive indicator is that $84 \%$ of respondents have a high level of learning motivation (Table 3 , criterion 1), and $82 \%$ of respondents have the ability to plan their work ahead (criterion 2) so that they can complete the tasks of distance learning. Only $50 \%$ of respondents (criterion 3 ) would be able to spend 5 hours per week on studying. This result could be related to an increased workload and lack of time, which are mentioned as factors influencing the acquisition of professional development.

Also, it is interesting to note that the research has a small number of respondents (5\%) who do not support distance learning but believe that medicine can only be acquired through on-site seminars, 
lectures and practices. According of author I. Ivanova (2016), such an outcome can be explained by the individual's learning style, as well as a small share of adults who are not prepared to study independently, therefore special attention should be paid to the development of a support system for studies, the main objective of which is to promote the learning of the individual and thus the process of acquiring knowledge and actual competences in accordance with needs. Also, it must be understood that distance learning is not for everyone.

In the questionnaire respondents were asked to evaluate different digital tools (Table 4) and mark the tools important in distance learning. The results show that $59 \%$ of the respondents expect interactive lectures including audio, video and self-testing tasks, $37 \%$ expect online simulations and clinical cases from a distance learning course, while $36 \%$ of respondents want to see videos appropriate to our practice, in Latvian. Such a result is related to the previously mentioned factor of access to courses in English, as well as different approaches to care in other countries.

Digital Material Priority in Distance Learning and Previous Experience

Table 4

$(\%)(\mathrm{n}=247)$

\begin{tabular}{|l|c|c|}
\hline \multicolumn{1}{|c|}{ Digital tools for distance learning } & $\begin{array}{c}\text { Tools } \\
\text { required } \\
\text { for distance } \\
\text { learning }\end{array}$ & $\begin{array}{c}\text { Previously } \\
\text { used by } \\
\text { respondents }\end{array}$ \\
\hline Interactive lectures including audio, video and self-testing tasks. & 59 & 39 \\
\hline Online simulations, clinical cases. & 37 & 4 \\
\hline Video materials that relate to our practice, in Latvian. & 36 & 12 \\
\hline Readable materials - pdf, Word, PowePoint. & 32 & 62 \\
\hline Online lectures with the option to ask questions. & 26 & 7 \\
\hline Recorded PowerPoint lectures. & 26 & 54 \\
\hline Recorded online lectures. & 22 & 27 \\
\hline Readable materials - online books. & 21 & 26 \\
\hline $\begin{array}{l}\text { Different links to other web addresses where additional information } \\
\text { is available. }\end{array}$ & 20 & 33 \\
\hline $\begin{array}{l}\text { Online educational games, tests, flash cards and other tools, forums, } \\
\text { discussion boards. }\end{array}$ & 14 & 7 \\
\hline Various video materials (e.g. YouTube) in English, Russian, Latvian. & 13 & 26 \\
\hline
\end{tabular}

Today, the content of distance learning courses extends far beyond printed books, reaching an interactive multimedia environment that combines the separation between content, virtual environment and teaching, and between learning and interaction. In order to achieve the course objective, the course author needs to evaluate the necessity of each digital material and tool, and for which purpose the material is being used.

When assessing the experience of respondents using digital tools, it was found that the vast majority of respondents know and use many tools; it turned out that the majority (62\%) of respondents use readable materials in pdf, word or PowerPoint, which is one of the most commonly used resources for distance learning and e-studies; while $54 \%$ of respondents have used recorded audio presentations that are currently available for the professional development of medical practitioners in Latvia as a distance learning tool (Table 4).

\section{Conclusion}

The professional development of medical practitioners within distance learning is a supported form of study related to the high self-motivation of respondents, which in turn is associated with economic benefits, saving time and money. To ensure that the distance learning course for the professional development of medical practitioners is aimed precisely at the interests and wishes of the participants various digital learning tools should be included in the course. This would increase students' motivation and they would 
not lose interest in the course. Also, learning a language is important. In order to effectively acquire teaching materials, they must be prepared in accordance with the language skills of the course participant, excluding foreign literature in the course, adding it only as supplementary literature. An interactive distance learning course, which includes various clinical simulations, can meet the expectations of course participants and increase the motivation for acquiring a distance learning course.

The readiness of medical practitioners is determined by technological knowledge and provision, but apart from that the course must be easy to use, and other non-technology-related criteria may affect acquisition of the course. In order to provide support to the course participant individually based on her or his needs, it is recommended that each course participant evaluates the readiness and anticipates future problems prior to the course visit. The respondents' overall level of readiness is high; there is a $70 \%$ of respondents who have a desire to use distance learning, but they have poor technological skills. The lack of time and time planning is one of the factors influencing distance learning; therefore, student support and advice is an important condition for the implementation of any distance learning course.

\section{Bibliography}

1. Baran E. (2014). A Review of Research on Mobile Learning in Teacher Education. Educational Technology and Society, 17(4), 17-32. Retrieved from http://www.ifets.info/journals/17 4/2.pdf

2. Bates A.W. (2016). Teaching in a Digital Age. Guidelines for Designing Teaching and Learning. CA: Creative Commons Attribution-NonCommercial 4.0. International Licence. Retrieved from https://teachonline.ca/sites/default/files/pdfs/teaching-in-a-digital-age 2016.pdf

3. Bullock A., Bailey S., Cowpe J., Barnes E., Thomas H., Thomas R., Akota I. (2013). Continuing Professional Development Systems and Requirements for Graduate Dentists in the EU: Survey Results from the DentCPD Project. European Journal of Dental Education, 17(1), 77-81. Retrieved from https://www.ncbi.nlm.nih.gov/pubmed/23279418

4. Clark D., Frith K. (2013). Distance Education in Nursing. (3rd. ed.). New York: Springer Publishing Company.

5. Continuing Education, Professional Development and Lifelong Learning for the 21st Century Health Care Workforce. (2011). US: Advisory Committee on Interdisciplinary, Community-Based Linkages (ACICBL). Retrieved from https://www.hrsa.gov/advisorycommittees/bhpradvisory/acicbl/Reports/eleventhreport.pdf

6. E-learning Quality. Aspects and Criteria for Evaluation of E-learning in Higher Education. (2008). Stockholm: Swedish National Agency for Higher Education. Retrieved from http://www.eadtu.nl/e-xcellencelabel/files/0811R.pdf

7. Hart C. (2012). Factors Associated with Student Persistence in an Online Program of Study. A Review of the Literature. Journal of Interactive Online Learning, 11 (1), 19-42. Retrieved from http://www.ncolr.org/jiol/issues/pdf/11.1.2.pdf

8. Hung M.L., Chou C., Chen C.H., Own Z.Y. (2010.). Learner readiness for online learning: Scale development and student perceptions. Computers and Education, 55, 1080-1090. Retrieved from http://www.anitacrawley.net/Articles/Hung.pdf

9. Ivanova I. (2016). Pieaugusho macishanas ipatnibas (Features of Adult Teaching). Brussels: European Commission, EPALE. Retrieved from https://ec.europa.eu/epale/lv/resourcecentre/content/pieauguso-macisanas-ipatnibas (in Latvian).

10. Knowles M.S., Holton E.F., Swanson R.A. (2015). The Adult Learner: The Definitive Classic in Adult Education and Human Resource Development (5th ed.). Routledge. Taylor and Francis Group.

11. McVay M. (2001). How to be a Successful Distance Learning Student: Learning on the Internet. New York: Prentice Hall.

12. Mercado C.A. (2008). Readiness Assessment Tool for an eLearning Environment Implementation. In S. Charmonmam (Ed.), Proceedings of the Fifth International Conference on eLearning for Knowledge-Based Society, 16. Bangkok, Thailand: The Ministry of Information and Communication Technology. Retrieved from https://pdfs.semanticscholar.org/3035/f59636fd52e3e6224c2337720c0c514fd3d8.pdf

13. Merriam S.B., Cafarella R.S., Baumgartner L.M. (2007). Learning in Adulthood: a Comprehensive Guide (3rd ed.). San Francisco: John Wiley and Sons.

14. Open and Distance Learning. Trends, Policy and Strategy Considerations. (2002). Paris, France: UNESCO. Retrieved from http://unesdoc.unesco.org/images/0012/001284/128463e.pdf 
15. Ozgur A.Z., Kocak N.G. (2016). Global Tendencies in Open and Distance Learning. Journal of Education and Human Development. 5(4), 202-210. Retrieved from http://jehdnet.com/journals/jehd/Vol 5 No 4 December 2016/19.pdf

16. Par pamatnostadnem "Cilvekresursu attistiba veselibas aprupe" (Guidelines on "Development of Human Resources in Healthcare). (2005). Riga: Ministru kabineta rikojums Nr.326. Retrieved from https://likumi.lv/doc.php?id=108598 (in Latvian).

17. Pawlowski J.M. (2007). The Quality Adaptation Model: Adaptation and Adoption of the Quality Standard ISO/IEC 19796-1 for Learning, Education, and Training. Educational Technology and Society, 10 (2), 3-16. Retrieved from http://www.ifets.info/journals/10_2/2.pdf

18. Poljanowicz W., Roszak M., Kolodziejczak B., Breborowicz A. (2014). An Analysis of the Effectiveness and Quality of E-learning in Medical Education. Retrieved from https://depot.ceon.pl/bitstream/handle/123456789/11789/13 AN\%20ANALYSIS\%20OF\%20TH E\%20EFFECTIVENESS.pdf?sequence $=1$

19. Pozdnyakova O., Pozdnyakov A. (2017). Adult Students' Problems in the Distance Learning. Procedia Engineering, 178, 243-248.

20. Smith G.G., Passmore D., Faught T. (2009). The Challenges of Online Nursing Education. The Internet and Higher Education, 12(2), 98-103.

21. Smith P.J., Murphy K.L. Mahoney S. E. (2003). Towards Identifying Factors Underlying Readiness for Online Learning: An Exploratory Study. Distance Education, 24(1), 57-67.

22. Vasilevska D., Rivza B., Bogdan R. (2017). Evaluation of Readiness for Distance Education of Students in European Universities. Broad Research in Artificial Intelligence and Neuroscience, 8(1), 35-41. 